\title{
Equivalents of the Genitive in Other Languages ${ }^{\dagger}$
}

\author{
E. A. NIDA
}

Having now considered the range of usage and meaning of the genitive case in Greek, we should note briefly the practical application of such distinctions in translating into languages which have an entirely different structure from English. We need not treat all the types of expressions, for some are relatively simple, but some require careful scrutiny. We surely cannot expect many other languages to have a similar particle such as "of," which so conveniently (though with considerable ambiguity) corresponds to the genitive construction in Greek.

The first important problem encountered by the translator is in rendering the objective and subjective genitives. In numerous cases the entire sentence structure must be revamped in order to place the subject and object components in their right relationships to the words of process or state which occur. For example, in John 2:6 the phrase "according to the cleansing of the Jews" must often be rendered "according as the Jews cleanse" (or "cleanse themselves," if a reflexive form of the verb is required). "The Jews" is actually the subject of the process of "cleansing," and in many languages the only way in which this relationship may be clearly identified is to make the subject element the actual grammatical subject of a verb. In II Corinthians 10:5 the objective expression "the obedience of Christ" may require a verb-object construction such as "making captive every thought so that it will obey Christ."

In the translation of II Corinthians $13: 14$

these qualities are simply the possessions of the three Persons of the Trinity, but each word identifies an active process of bestowing a spiritual benefit upon men. In the phrases "the grace of the Lord Jesus Christ, and the love of God, and the fellowship of the Holy Spirit, be with you all" one is not reckoning simply with the grace which the Lord Jesus Christ possesses, or the love which is the innate quality of God, or the fellowship owned by the Holy Spirit. These are not possessive relationships, but in each case the members of the Trinity are the subject elements of the spiritual processes. The way in which this passage may be translated into some languages is, "May the Lord Jesus Christ look upon you all for good (this is the translation of "grace" in Bolivian Quechua), and may God love you all, and may the Holy Spirit have fellowship with you all." This type of rendering changes the syntactic arrangement in such a way that the actual logical subjects (i.e. the initiators of the action) become the grammatical subjects, and the nouns of process are changed into verbs of process.

The objective genitive relationship such as "the love of God" (I John $5: 3$ ) may be rendered in some cases by a verbal expression, e.g. "For this is loving God, that we keep his commandments...." (or, "what he commands...."). In some instances the grammatical requirements of the language force us to change the subject and predicate elements so that we have "For loving God is this, namely, keeping his one may encounter added difficulties be-0Grymandments....".

cause the words corresponding to "grace," "love," and "fellowship" (A. V. "commun- The genitive of source may be treated in ion") are more often than not translated as a number of ways, but in II Corinthians verbs rather than as nouns. Certainlyeach of these stands for a process, not a thing. Theprinted by permission from The Bible The meaning of the passage is not that Translator, Vol. I, No. 2, April 1950. 
in perils of robbers" may be rendered "in perils because of rivers and in perils because of robbers."

Genitive of substance or material often require some type of explanatory identification or an appositional construction. For example, "a patch of unshrunk cloth" (Mark 2:21) may be rendered "a patch which is (or, is made of) unshrunk cloth." This use of "which is" might appear to be the only way to identify the relationship of substance to object. In John $2: 21$ "the sanctuary of his body" identifies a relationship in which the second element actually identifies the nature of the first. Such a phrase may be rendered by "the sanctuary, which is his body" or "the sanctuary, that is, his body."

As was indicated above, the relationship between the primary word of the phrase and the genitive attributive may be very poorly defined. For example, in Mark 1:4 the phrase "did.... preach the baptism of repentance" has in some languages been translated "preached that men should repent and be baptised." This type of translation is particularly necessary where the language possesses no nouns for the two words of process, namely, "baptism and "repentance." The most that we can understand from the genitive construction which underlies the relationship of these words is that the baptism had reference to repentance, or that repentance was associated with baptism. In some languages the only way to combine such loosely related ideas is to employ an "and."

We are frequently inclined to think that the entire meaning of passages is carried simply by the roots of the words. This is by no means true, for grammatical combinations of words also have their meanings, often very extensive and complicatd. The accurate analysis of the words is very important, but equally important, and sometimes much more difficult, is the proper identification of the meaning of grammatical constructions.

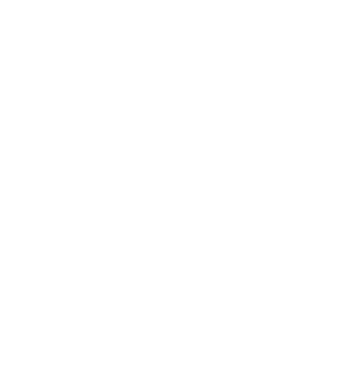

